\title{
TINJAUAN YURIDIS PUTUSAN NOMOR 38/PID.SUS/2019.MTK DALAM USAHA PERTAMBANGAN RAKYAT (TIMAH) YANG DILAKUKAN SIN HO ALIAS AHO DI KABUPATEN BANGKA BARAT
}

\author{
Widya Natalia Halim ${ }^{1)}$, Elsi Kartika Sari ${ }^{2)}$ \\ 1,2) Fakultas Hukum Universitas Trisakti) \\ Corresponding Author: elsi,ks@trisakti.ac.id,widyahalim77@gmail.com
}

\begin{abstract}
ABSTRAK
Pengambilan kekayaan alam dalam perut bumi diatur khusus dalam UU No. 4 Tahun 2009. Usaha Pertambangan adalah kegiatan dalam rangka pengusahaan mineral atau batubara yang meliputi tahapan kegiatan penyelidikan umum, eksplorasi, studi kelayakan, konstruksi, penambangan, pengolahan dan pemurnian, pengangkutan dan penjualan, serta pascatambang, supaya mendapatkan izin pertambangan, pemohon harus memenuhi persyaratan administrasi, teknis lingkungan dan finansial. Usaha petambangan diperlukan Izin Usaha Pertambangan. Metode penelitian yuridis, menggunakan data sekunder, dianalisis secara kualitatif, keseimpulan secara logika dedutif. Dalam pekara Nomor 38/PID.SUS/2019.MTK terhadap SIN HO alias AHO. Pertambangan rakyat yang dilakukan di Dusun Suntai Desa Air Gantang Kecamatan Parittiga, Kabupaten Bangka Barat, telah beroperasi kurang lebih selama 3 hari menggunakan alat sederhana (mesin pompa, pipa, dan selang). Majelis Hakim menyatakan perbuatan Penambangan yang dilakukan Sin Ho tanpa memiliki IUP, IUPR dan IUPK dalam ketentuan berikut: Pasal 37, Pasal 40 ayat (3), Pasal 48, Pasal 67 ayat (1), Pasal 74 ayat (1) dan ayat (2) UU No. 4 Tahun 2009. Oleh Karena itu Hakim menggunakan Perda Provinsi Kepulauan Bangka Belitung No, 7 Tahun 2014 jo Pasal 158 UU No. 4 Tahun 2009, namun memberi sanksi pidana 10 (sepuluh) bulan penjara dan denda sebesar Rp. 1.000.000,00 (satu juta rupiah) tidak sesuai yang diatur dalam peraturan yang berlaku.
\end{abstract}

Kata Kunci: Izin Usaha Pertambangan Rakyat, Hukum Pertambangan

\section{PENDAHULUAN}

Penguasaan kekayaan alam oleh negara diperlukan secara khusus untuk diatur oleh Undang-Undang supaya tidak menimbulkan kesalahan dalam pelaksanaan kegiatan penguasaan kekayaan alam. Pengambilan kekayaan alam dalam perut bumi diatur khusus dalam Undang-Undang Nomor 4 Tahun 2009 Tentang Pertambangan Mineral dan Batu Bara.

Undang-Undang tersebut mengatur tentang kegiatan pertambangan mulai dari izin usaha pertambangan hingga kegiatan pascatambang, serta hak menguasai negara. Penguasaan kekekayaan alam tersebut oleh negara diselenggarakan Pemerintah. 
Semua bahan tambang yang berada di seluruh wilayah Indonesia dikuasai oleh negara dan diperuntukan sebesar besarnya untuk kemakmuran rakyat, sebagaimana tercantum dalam Pasal 33 ayat (3) Undang-Undang Dasar 1945: " bumi, air, dan kekayaan alam yang terkandung didalamnya dikuasai oleh negara dan dipergunakan untuk sebesar-besarnya rakyat. ${ }^{1}$

Kewenangan negara untuk menguasai sumber daya alam dinyatakan dalam pasal 2 ayat 2 dan ayat 3 UUPA yang mengatur pengambilan kekayaan alam yang terkandung dalam bumi, air, dan ruang angkasa serta Pasal 8 UUPA menyebutkan bahwa pengambilan kekayaan alam yang terkandung dalam bumi, air dan ruang angkasa perlu diatur. Karena hak-hak atas tanah itu hanya memberi hak atas permukaan bumi dan tidak untuk mengambil kekayaan alam yang terkandung dalam tubuh bumi memerlukan pengaturan secara tersendiri. ${ }^{2}$

Untuk mewujudkan kemakmuran tersebut pertambangan harus dikelola dan dimanfaatkan secara optimal. Dikarenakan selama ini pengelolaan tambang lebih mengutamakan keuntungan ekonomi sebesar-besarnya. Oleh karena itu suatu tambang akan menjadi pemicu pembangunan dan pengembangan daerah tertinggal dan memberikan dampak ganda yang postif dalam berbagai sektor.

Usaha Pertambangan adalah kegiatan dalam rangka pengusahaan mineral atau batubara yang meliputi tahapan kegiatan penyelidikan umum, eksplorasi, studi kelayakan, konstruksi, penambangan, pengolahan dan pemurnian, pengangkutan dan penjualan, serta pascatambang.

Supaya mendapatkan izin pertambangan, pemohon harus memenuhi persyaratan administrasi, teknis lingkungan dan finansial. Untuk melakukan usaha petambangan diperlukan izin usaha pertambangan. Pemberian Izin Usaha Pertambangan (IUP) yang dikenal konsep Wilayah Pertambangan dijadikan landasan dalam penetapan kegiatan pertambangan.

IUP diberikan kepada badan usaha, koperasi dan perseorangan. Berdasarkan Pasal 36 ayat (1) dan (2) Undang-Undang Nomor 4 tahun 2009 Tentang Mineral dan Batubara: IUP terdiri atas dua tahap yakni:

1. IUP Eksplorasi meliputi kegiatan penyelidikan umum, eksplorasi, dan studi kelayakan.

2. IUP Operasi produksi meliputi kegiatan konstruksi, penambangan, pengolahan dan pemurnian, serta pengangkutan dan penjualan.

Kegiatan pertambangan tidak hanya berdasarkan izin usaha pertambangan, Namun proses pemberian IUP yang dikenal konsep Wilayah Pertambangan dijadikan landasan dalam penetapan kegiatan pertambangan. Izin Usaha Pertambangan diberikan oleh bupati/walikota apabila berada didalam wilayah kabupaten/kota, diberikan oleh gubernur apabila berada pada lintas wilayah kabupaten/kota dalam 1(satu) provinsi setelah mendapat rekomendasi

\footnotetext{
${ }^{1}$ Undang-Undang Dasar 1945, Pasal 33 ayat (3).

2 Boedi Harsono, Hukum Agraria Indonesia Sejarah Pembentukan Undang-Undang Pokok Agraria, (Jakarta: Djambatan, 2005), h. 19.
} 
bupati/walikota dan diberikan menteri apabila wilayah usaha pertambangan berada pada lintas wilayah provinsi setelah rekomendasi gubernur dan bupati/walikota. Izin Usaha Pertambangan diberikan kepadan Perseorangan, koperasi dan Badan Usaha.

Salah satu Kabupaten yang banyak melakukan penambangan Timah adalah Bangka Barat merupakan salah satu pencahariannya adalah tambang untuk memenuhi kebutuhan hidup mereka. Jumlah produksi timah pada tahun 2015 yaitu 17.551,054 ton dan logam timah mencapai 19.065 ton, selain itu dikarenakan eksploitasi sumber daya tambang dapat merusak lingkungan, maka perlu diperhatikan kelestarian lingkungan agar tidak terjadi pencemaran dan pengerusakan lingkungan hidup. Banyak masyarakat Bangka Barat terutama di Kabupaten Mentok melakukan kegiatan pertambangan rakyat yang dilakukan tanpa adanya izin usaha pertambangan sehingga menyebabkan banyaknya penambangan liar yang terjadi di daerah tersebut dan tanpa adanya pengawasan dari pihak yang berwenang.

Kabupaten Bangka Barat memiliki banyak penambang liar yang tidak bertanggung jawab dan menyebabkan kerusakan lingkungan. Hal tersebut juga menimbulkan dampak negatif kepada lingkungan dan masyarakat sekitar akibat kegiatan penambangan liar yang terjadi. Dapat dilihat dalam salah satu kasus tahun 2019 di Kabupaten Bangka Barat, berawal dari laporan masyarakat yang didapat, bahwa adanya penambang liar melakukan kegiatan penambangan timah di Kabupaten Bangka Barat dengan mengunakan mesin pompa, mesin robin dll. Berdasarkan keterangan bahwa pelaku tambang adalah mereka yang bekerja kepada penyedia fasilitas penambang timah seperti yang dilakukan oleh SIN HO ALIAS AHO. Berdasarkan uraian diatas bagaimana keputusan Hakim terhadap pertambangan perorangan dalam putusan nomor 38/Pid.Sus/2019.Mtk berdasarkan Undang-Undang No. 4 Tahun 2009 tentang Pertambangan Mineral dan Batubara.

\section{Pembahasan}

Usaha Pertambangan adalah kegiatan dalarn rangka pengusahaan mineral atau batubara yang meliputi tahapan kegiatan penyelidikan umum, eksplorasi, studi kelayakan, konstrultsi, penambangan, pengolahan dan pemurnian, pengangkutan dan penjualan, serta pascatambang.

Usaha pertambangan dilaksanakan dalam 3 (tiga) bentuk, yaitu Izin Usaha Pertambangan (IUP), Izin Pertambangan Rakyat (IPR), dan Izin Usaha Pertambangan Khusus (IUPK).

Pertambangan Rakyat adalah suatu usaha pertambangan bahan-bahan galian dari semua golongan yang dilakukan oleh rakyat setempat secara kecilkecilan atau secara gotong royong dengan alat sederhana untuk mata pencaharian sendiri. 
Izin Pertambangan Rakyat, yang selanjutnya disebut IPR, merupakan izin untuk melaksanakan usaha pertambangan dalam wilayah pertambangan rakyat dengan luas wilayah dan investasi terbatas. ${ }^{3}$ Dalam Pasal 68 ayat (1) UndangUndang Nomor 4 Tahun 2009 tentang Pertambangan Mineral Dan Batu Bara diatur mengenai luas wilayah untuk 1 (satu) IPR yang dapat diberikan kepada :

1. Perseorangan paling banyak 1 (satu) hektar

2. Kelompok masyarakat paling banyak 5 (lima) hektar, dan/atau

3. Koperasi paling banyak 10 (sepuluh) hektar

IPR diberikan oleh Bupati/walikota terutama kepada penduduk setempat, baik perseorangan maupun kelompok masyarakat dan/atau koperasi. Untuk memperoleh IPR pemohon wajib menyampaikan surat permohonan kepada bupati/walikota dengan disertai meterai cukup dan dilampiri rekomendasi dari kepala desa/lurah/kepala adat mengenai kebenaran riwayat pemohon untuk memperoleh prioritas dalam mendapatkan IPR.

Pemberian Izin Usaha Pertambangan rakyat di Bangka Barat, iatur dalam Peraturan Daerah Provinsi Kepulauan Bangka Belitung Nomor 7 Tahun 2014 Tentang Pengelolaan Pertambangan Mineral dan Peraturan Gubernur Kepulauan Bangka Belitung Nomor 59 Tahun 2017 Tentang Tata Cara Pemberian Wilayah Izin Usaha Pertambangan Mineral Bukan Logam Dan Batuan, Penyesuaian Izin Usaha Pertambangan Dan Izin Usaha Pertambangan Afiliasi Serta Izin Pertambangan Rakyat sebagai pelaksanaan Pasal 6 dan pasal 7 UU No. 4 Tahun 2009 sehingga setiap orang atau badan hukum harus memenuhi ketentuan tersebut harus mempunyai Izin Usaha Pertambangan sesaui denga Wilayah Pertambangannya.

Dalam pekara yang dilakukan oleh SIN HO alias AHO adalah Pertambangan rakyat yang terjadi dilakukan di Dusun Suntai Desa Air Gantang Kecamatan Parittiga, Kabupaten Bangka Barat, dimana kegiatan pertambangan tersebut telah beroperasi kurang lebih selama 3 hari menggunakan alat sederhana (mesin pompa, pipa, dan selang). ${ }^{4}$ Sin Ho sebagai pemilik TI (Tambang Inkonvensional) dan mengawasi penambangan pasir timah dalam 1 (satu) hari Sin Ho bisa mendapatkan pasir timah sebanyak 5 (lima) kg, kemudian pasir timah langsung dijual oleh Sin Ho kepada pembeli yang berada di Kecamatan Parittiga Kabupaten Bangka Barat seharga Rp 100.000,- (seratus ribu rupiah) per/kg, kemudian uang hasil penjualan pasir timah dibagi kepada pekerja tambang sebesar Rp35.000,(tiga puluh lima ribu rupiah) per/kg dan uang bersih yang di dapat Sin Ho per/hari sebesar Rp100.000,- (seratus ribu rupiah).

Berdasarkan Peraturan Daerah Bangka Barat Sin Ho alias AHO seharusnya memiliki IUP dan IPR sebab sebagaimana diatur pada ketentuan UU No. 4 Tahun 2009 jo Perda Provinsi Kepulauan Bangka Belitung Nomor 7 Tahun 2014 jo Perda Gubernur Nomor 59 Tahun 2017 untuk melakukan pertambangan mineral dan batubara, pelaku usaha harus mendapatkan izin usaha. Usaha pertambangan

\footnotetext{
${ }^{3}$ Undang-Undang Nomor 4 Tahun 2009, tentang Pertambangan Mineral Dan Batu Bara, Pasal 1 ayat 10.

4 informasi yang didapatkan dari masyarakat yaitu Agustian dan Taufik adalah anggota kepolisian.
} 
dilakukan dalam bentuk Izin Usaha Pertambangan (IUP) dan Izin Usaha Pertambangan Rakyat (IPR) persyaratan yang harus dilengkapi adalah persyaratan administratif, teknis, lingkungan, serta finansial. Izin Pertambangan Rakyat diberikan untuk jangka waktu paling lama 5 (lima) tahun dan dapat diperpanjang sebanyak 2 (dua) kali masing-masing dengan jangka waktu paling lama 2 (dua) tahun sesuai dengan pasal 21 ayat 2 Peraturan Kepulauan Bangka Belitung Nomor 59 Tahun 2017.

Berdasarkan bukti yang diberikan dan pengakuan Sin $\mathrm{Ho}$ alias $\mathrm{AHO}$, ma pertimbangan hukumnya Majelis hakim menyatakan bahwa perbuatan Penambangan yang dilakukan Sin Ho tanpa memiliki IUP, IUPR dan IUPK sebagaimana yang dimaksud dalam ketentuan berikut: Pasal 37, Pasal 40 ayat (3), Pasal 48, Pasal 67 ayat (1), Pasal 74 ayat (1) dan ayat (2).

Oleh karena itu dalam Putusan Pengadilan Nomor 38/Pid.Sus/2019.Mtk, Hakim, menerapkan Pasal 158 Undang-Undang Nomor 4 Tahun 2009 tentang Mineral dan Batubara terhadap pelanggaran yang dilakukan oleh Sin Ho alias Aho, yang merumuskan bahwa setiap orang yang melakukan usaha penambangan tanpa IUP, IPR atau IUPK sebagaimana dimaksud dalam Pasal 37, Pasal 40 ayat (3), Pasal 18, Pasal 67 ayat (I), Pasal 74 ayat (1) atau ayat (5) dipidana dengan pidana penjara paling lama 1.0 (sepuluh) tahun dan denda paling banyak Rp 10.000.000.000,00 (sepuluh miliar rupiah). Selain ketentuan sebagaimana dimaksud dalam Pasal 158, Pasal 159, Pasal 160, Pasal 161, dan Pasal 162 kepada pelaku tindak pidana dapat dikenai pidana tambahan berupa:

a. Perampasan barang yang digunakan dalam melakukan tindak pidana;

b. Perampasan keuntungan yang diperoleh dari tindak pidana; dan atau

c. Kewajiban membayar biaya yang timbul akibat tindak pidana.

Terhadap Sin Ho juga dapat diterapkan ketentuan Pasal 115 Peraturan Daerah Provinsi Kepulauan Bangka Belitung Nomor 7 Tahun 2014 selain ketentuan sebagaimana dimaksud dalam Pasal 108, Pasal 109, Pasal 110, Pasal 111 dan Pasal 112 kepada pelaku tindak pidana dapat dikenai pidana tambahan berupa :

a. Perampasan barang yang digunakan dalam melakukan tindak pidana;

b. Perampasan keuntungan yang diperoleh dari tindak pidana; dan/atau

c. Kewajiban membayar biaya yang timbul akibat tindak pidana. ${ }^{5}$

Dalam amar Keputusan yang diberikan oleh Hakim dalam putusan Nomor 38/Pid.Sus/2019 dalam kasus Sin Ho alias Aho hanya menjatuh Menjatuhkan pidana terhadap Terdakwa oleh karena itudengan pidana penjara selama 10 (sepuluh) bulan dan denda sejumlah Rp1.000.000,00 (satu juta rupiah) dengan ketentuan apabila denda tersebut tidak dibayar diganti dengan pidana kurungan selama 1 (satu) bulan. Hal ini tidak sesuai seperti apa yag diatur dalam UU No. 4 Tahun 2009 jo Peraturan Daerah Provinsi Kepulauan Bangka Belitung Nomor 7 Tahun 2014, namun kurang memberikan efek jera dikarenakan memberikan hukum cukup ringan terhadap masyakarat yang telah melakukan pertambangan

\footnotetext{
${ }^{5}$ Peraturan Daerah Provinsi Kepulauan Bangka Belitung Nomor 7 Tahun 2014, Pasal 115.
} 
ilegal.

\section{KESIMPULAN}

Pertambangan Rakyat adalah suatu usaha pertambangan bahan-bahan galian dari semua golongan yang dilakukan oleh rakyat setempat secara kecilkecilan atau secara gotong royong dengan alat sederhana untuk mata pencaharian sendiri. Pemberian Izin Usaha Pertambangan rakyat di Bangka Barat, diatur dalam Perda Provinsi Kepulauan Bangka Belitung No. 7 Tahun 2014 jo Peraturan Gubernur Kepulauan Bangka Belitung Nomor 59 Tahun 2017 serta Izin Pertambangan Rakyat sebagai pelaksanaan Pasal 6 dan pasal 7 UU No. 4 Tahun 2009 sehingga setiap orang atau badan hukum harus memenuhi ketentuan tersebut harus mempunyai Izin Usaha Pertambangan sesaui denga Wilayah Pertambangannya. Perbuatan pertambangan yang dilakukan Sin $\mathrm{Ho}$ alias $\mathrm{AHO}$ tersebut, Majelis hakim menyatakan bahwa perbuatan Penambangan yang dilakukan Sin Ho tanpa memiliki IUP, IUPR dan IUPK yang merumuskan bahwa setiap orang yang melakukan usaha penambangan tanpa IUP, IPR atau IUPK menerapkan Pasal 158 Undang-Undang Nomor 4 Tahun 2009 yang dimaksud Pasal 37, Pasal 40 ayat (3), Pasal 18, Pasal 67 ayat (I), Pasal 74 ayat (1) atau ayat (5) dipidana dengan pidana penjara paling lama 10 (sepuluh) tahun dan denda paling banyak Rp 10.000.000.000,00 (sepuluh miliar rupiah0, namun amar Keputusan yang diberikan oleh Hakim dalam putusan Nomor 38/Pid.Sus/2019 dalam kasus Sin Ho alias Aho hanya menjatuh Menjatuhkan pidana terhadap Terdakwa oleh karena itudengan pidana penjara selama 10 (sepuluh) bulan dan denda sejumlah Rp1.000.000,00 (satu juta rupiah) dengan ketentuan apabila denda tersebut tidak dibayar diganti dengan pidana kurungan selama 1 (satu) bulan. Hal ini tidak sesuai seperti apa yag diatur dalam UU No. 4 Tahun 2009 jo Peraturan Daerah Provinsi Kepulauan Bangka Belitung Nomor 7 Tahun 2014, namun kurang memberikan efek jera dikarenakan memberikan sanksi cukup ringan terhadap masyakarat yang telah melakukan pertambangan ilegal

\section{DAFTAR PUSTAKA}

Undang-Undang Dasar 1945

Boedi Harsono, Hukum Agraria Indonesia Sejarah Pembentukan Undang-Undang Pokok Agraria, (Jakarta: Djambatan, 2005)

Undang-Undang Nomor 4 Tahun 2009, tentang Pertambangan Mineral Dan Batu Bara

Peraturan Daerah Provinsi Kepulauan Bangka Belitung Nomor 7 Tahun 2014 